\title{
Optimization of Precious Metal Recovery from Waste Electrical and Electronic Equipment Boards
}

\author{
Massimo Delfini ${ }^{1}$, Mauro Ferrini ${ }^{1}$, Andrea Manni ${ }^{2 *}$, Paolo Massacci ${ }^{1,2}$, Luigi Piga ${ }^{1}$, Antonio Scoppettuolo ${ }^{1}$ \\ ${ }^{1}$ Department of ICMA, University of Rome "La Sapienza" Via Eudossiana, Rome, Italy; ${ }^{2}$ Consorzio Inteuniversitario Nazionale \\ Ingegneria Georisorse, Via di Monte Giordano, Rome, Italy. \\ Email: andrea.manni@uniroma1.it
}

Received April 21 ${ }^{\text {st }}, 2011$; revised May $17^{\text {th }}, 2011$; accepted June $22^{\text {nd }}, 2011$.

\begin{abstract}
Recovering noble metals from Waste Electrical Electronic Equipment (WEEE) will provide an additional income within the disposal process of end-of-life electronic devices. Generally, the recycling process starts with the manual dismantling of different devices and with sorting of the subdivided products into useful and hazardous materials. A sample of about 21 tonnes of WEEE was dismantled in 14 days to remove Printed Circuit Boards (PCBs) that were about 5\% weight of the whole sample. Computer PCBs proved to contain the $96 \%$ of all the gold present in all types of PCBs of the sample. Computer PCBs were manually dismantled to obtain the easy-to-remove components of the board, namely, the integrated circuits and the processors, which were about $13 \%$ weight of the board and $0.1 \%$ weight of the whole WEEE sample and contained about $91 \%$ of the gold present in the whole board with an average concentration of 2400 $\mu g / g$.
\end{abstract}

Keywords: WEEE, Recycling, Waste Processing, Precious Metals

\section{Introduction}

The amount of electronic scrap is increasing all over the world and each European inhabitant produces about 20 $\mathrm{kg}$ each year. Generally, the final destination of such waste should be a landfill with a high level of environmental protection, due to the content of hazardous compounds. According to the European Commission, the waste stream of electronic and electrical equipment has been identified as one of the fastest growing waste streams in the EU, at present being less in quantity than Municipal Solid Waste (MSW) but increasing, annually by more than the growth of MSW. The situation is bound to worsen because the average life-time of a single computer is decreasing and thus the replacement frequency is growing. Moreover, LCD and plasma monitors of both computers and TV-sets will substitute the old cathode ray tube monitors (CRT), increasing the amount of waste to dispose of.

The Waste Electrical and Electronic Equipment Directive (WEEE Directive, 2002/96/EC), issued by the European Commission aims to minimise the impact of end-oflife electrical and electronic goods on the environment, by increasing re-use and recycling and then reducing the amount of WEEE used for landfill. A decision of the Commission stated that, within December 2006, $4 \mathrm{~kg}$ WEEE/inhabitant should have been collected yearly. Nevertheless, at present, $19 \mathrm{~kg} /$ inhabitant are collected in Sweden, $16 \mathrm{~kg} /$ inhabitant in Norway but less than 2 $\mathrm{kg} /$ inhabitant in Italy. According to the Italian Environmental Ministy, 938 ktonnes of WEEE were disposed of in a controlled landfill in 2006 and a large part of this came from the domestic circuit. The total quantity of waste generated from the professional circuit should be added to that amount, but this figure is not available to Public waste control bodies. Part of WEEE comes from the information technology sector and 220 ktonnes wastes were produced in Italy in 2008 but 126 ktonnes were not controlled, this amount corresponding to about 4 millions of computers, printers or screens. The cost of legal collection and disposal is expensive, and waste can be shipped abroad only if the receiving plants are equipped to treat and disposed of the waste safely. It has been supposed that a large part of WEEE from the professional circuit, is sent to underdeveloped countries disguised as working second-hand appliances, but $90 \%$ of that is only a waste that is dumped and stockpiled in improvised landfills without any environmental protection. 
The price of the second-hand appliances supports this hypothesis. In fact, the price of a single computer item or screen of about 3 euros for Indonesian buyers, for example, is absolutely out-of-market as the test to check whether a computer is running, before shipping abroad, is well above 3 euros. Moreover, the Italian law on waste management of waste if far from being enforced, and so an important fraction of WEEE produced in the domestic circuit, is still being left beside the rubbish skips. To avoid this, producers should be made responsible for financing the collection, treatment, and recovery of waste electrical equipment, and distributors should be obliged to allow private or professional consumers to return free of charge their end-of-life equipment when buying a new product. 10 product categories fall in the Directive, such as information technology and telecommunication equipment, medical devices, monitoring and control instruments, large and small household appliances.

Several authors have described the present status of the WEEE recycling in different countries such as Korea [1], Taiwan [2], the USA [3,4], China [5], Scotland [6], Greece [7], Germany [8], Switzerland [9], Sweden [10] and India [11].

There are 11.000 companies in Italy, producing Electrical and Electronic Equipment (EEE), with $212000 \mathrm{em}-$ ployes, chalking up a total turnover of 32 billion euro/y while there are 44 material recycling facilities (MRF) throughout the territory for the WEEE recycling.

Ten consortiums of producers consortia have been established since the approval of the WEEE Directive, which pay for the cost of collection and transport, accounting for most of the overall cost of recycling, to "eco-places" [12], where the end user can leave the WEEE, and from these to the MRFs. The above costs will probably be added to the selling cost of a new device and consortium will reach their own decision on whether to display this cost to consumers in the invoice, as is currently the case for the recycling plastic packaging, or to include it in the price.

WEEE recycling raises a large number of environmental issues, which can differ for each category of waste: $\mathrm{Ba}, \mathrm{Pb}, \mathrm{Hg}$ and rare earths, contained in $\mathrm{CRT}$ from TVs and Monitors and $\mathrm{Pb}, \mathrm{Cd}, \mathrm{Hg}$ contained in batteries could easily be leached if left in rubbish dumps, while Polybrominated Biphenyls (PBB), Polychloro Dibenzo Dioxins/Furans (PCDD/F), Polybrominated Diphenyl Ethers (PBDE), used as flame retardants in the plastic protection casings and condensers and in the printed boards, could spread in the environment if ignited. Likewise for Polychloro Biphenyls (PCB), contained in capacitors, and for phthalate, in plastics.

In most emerging countries backyard recyclers ignite the wastes in order to recover metals from the ashes, thereby creating considerable health problems to the workers and for the human community surrounding the workplaces.

This is the case, for example, for the major e-waste recycling towns in China namely Taizhou, Guiyu and Chendian, where increased levels of pollutants in body fluids has been reported; in particular dioxin [13], PCB [14], $\mathrm{Pb}, \mathrm{Cd}, \mathrm{Cu}$ [15], $\mathrm{Cr}$ [16], PBDE [17] and PAH [18].

WEEE scrap, without exception, contains Printed Circuit Boards (PCBs), whose overall composition has been reported [19] which are worth recycling to obtain the valuable elements contained, such as $\mathrm{Au}, \mathrm{Ag}, \mathrm{Pd}, \mathrm{Cu}$ and Al.

Therefore, recycling of WEEE, as secondary raw materials, is becoming extremely important due to their content of precious metals, i.e 50 - 60 time greater than in a normally mined ore; and the value can cover a large part of the costs both of recycling and of disposing of post-recycling end-of-life products.

Several authors have proposed different processes, based on physical and chemical methods, to recover the valuable components located in PCBs. The former involve crushing, milling, screening, magnetic separation, Eddy current separation and shaking table separation as the main methods. The latter involve hydrometallurgical [20] and pyrometallurgical methods [21].

Since PCBs contain more than $20 \%$ of $\mathrm{Cu}$ [2], after a preliminary shredding and milling process, they could be directly feed to copper or lead smelting plants: the main disadvantages of this process are the transport cost for the PCBs, as there are very few such plants in the world, and the environmental problems due to the back-formation (synthesis ex novo) of PCDD/F due to incomplete decomposition of precursors in flue gases when the temperature of the flue dust is in the range of $250-500^{\circ} \mathrm{C}$ $[22,23]$.

The aim of the present work is to identify the valuable components in the PCBs and to separate them from the board to minimize environmental impact, through a strong reduction in the volume of material to be processed for precious metal recovery in the successive steps. Statistically significant results have been obtained starting from a very large sample of WEEE, to reproduce a long working cycle for a typical MRF in Italy.

\section{Experimental Schemes}

Several schemes have been proposed for the preliminary treatment of different kind of WEEE. After collection and transport to MRF, any process should always start with the pre-treatment of sorting and manual dismantling of the WEEE, by means of tools such as screwdrivers, 
hammers and pliers and with the creation of different bulk of homogeneous materials. To perform such a manual job most efficiently, a preliminary sorting of WEEE into different categories should be carried out in eco-places. In this way, trucks going from eco-places to MRF could be loaded according to WEEE categories and unloaded in the opposite sequence in the large open space which each MRF is provided. This would allow manual dismantling with no preliminary sorting by operators. Unfortunately, at present, in the collecting sites, all the different items of equipment are kept together and are randomly transferred to the trucks for the transport to MRF where the sorting before disassembling is time consuming.

For the present study, a large sample of $20961 \mathrm{~kg}$ was collected in an Italian MRF of average size over a 14working day period to eliminate variations in feeding. A smaller random sample to be used for characterization was sampled from the larger one. Characterization was carried out on each component of this sample by chemical analyses according to the procedure described in the analytical method section.

\section{Analytical Method}

To determine the $\mathrm{Au}, \mathrm{Pd}$ and $\mathrm{Pt}$ content, $40 \mathrm{ml}$ of Aqua

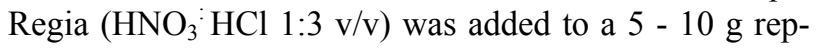
resentative sample and the solution was carefully heated until dissolution of the metallic components. After washing and filtering of the residue, the solution was brought to volume in a $250 \mathrm{ml}$ volumetric flask using
$\mathrm{HCl}$ 1:1 (v/v), to avoid $\mathrm{AgCl}$ precipitation [24,25].

Measurements were carried out, in triplicate, by means of ICP-OES (Perkin-Elmer Plasma 400) equipped with a monochromator with a spectral range of $160-800 \mathrm{~nm}$ covered by two gratings. After calibration with NIST traceable standards (O2SI Llc, Charleston, SC, USA), the elements were analysed in the wavelength having the best signal/noise ratio. No noteworthy interferences were noted. In order to prevent $\mathrm{AgCl}$ precipitation, $\mathrm{HCl} 1: 1$ $(\mathrm{v} / \mathrm{v})$ was employed to prepare standard, blank and flushing solutions.

\section{Results}

The results of sampling are reported in Table 1, where the different categories of waste are set out. $20961 \mathrm{~kg}$ of WEEE were collected in the plant in a 14-working day period with an average amount per day of $1497 \mathrm{~kg}$.

The PCBs from the three sources, namely, monitors, personal computers and TV-sets, account for the 5.54\% in weight of the overall sample for a daily average amount of $83 \mathrm{~kg}$, the amount of keyboards being negligible $(0.02 \%)$. The large amount of glass, $568 \mathrm{~kg}$ daily (about $38 \%$ of the whole sample) is due to the high specialization of the plant in processing CRT and TV screens. The above data are in reasonable agreement with those reported by other authors $[2,4]$.

A preliminary campaign of chemical analyses was carried out on each category of WEEE by means of a ran-

Table 1. Results of the sampling campaign for 14 days: for each day is reported the weight (kg) for each of the 11 different bulk of products ready to be further processed, the average per day and the quantity percentage of the overall WEEE.

\begin{tabular}{|c|c|c|c|c|c|c|c|c|c|c|c|c|c|c|c|c|c|}
\hline \multirow[b]{2}{*}{ Component } & \multicolumn{17}{|c|}{ Day of sampling } \\
\hline & 1 & 2 & 3 & 4 & 5 & 6 & 7 & 8 & 9 & 10 & 11 & 12 & 13 & 14 & $\begin{array}{c}\text { Total } \\
\mathrm{kg}\end{array}$ & $\begin{array}{c}\text { Av/day } \\
\mathrm{kg}\end{array}$ & $\begin{array}{l}\text { Qty } \\
(\%)\end{array}$ \\
\hline$C R T P C B$ & 31 & 46 & 49 & 54 & 76 & 92 & 40 & 97 & 60 & 104 & 45 & 53 & 95 & 70 & 912 & 65 & 4,4 \\
\hline РС $Р C B$ & 2 & 24 & 11 & 5 & 3 & 14 & 15 & 7 & 6 & 23 & 13 & 8 & 18 & 13 & 162 & 12 & 0.77 \\
\hline$T V P C B+K B$ & 0 & 0 & 32 & 2 & 4 & 0 & 10 & 8 & 12 & 4 & 0 & 0 & 6 & 0 & 78 & 6 & 0.37 \\
\hline$H D+F L$ & 2 & 36 & 26 & 0 & 0 & 3 & 6 & 3 & 0 & 18 & 0 & 8 & 16 & 17 & 135 & 10 & 0.64 \\
\hline $\begin{array}{c}\text { PLASTIC + } \\
\text { RESINS }\end{array}$ & 168 & 236 & 297 & 247 & 164 & 288 & 247 & 287 & 251 & 400 & 457 & 172 & 461 & 340 & 4015 & 287 & 19 \\
\hline $\begin{array}{c}\text { FERROUS } \\
\text { MATERIAL. }\end{array}$ & 211 & 539 & 688 & 157 & 157 & 247 & 489 & 143 & 248 & 312 & 408 & 93 & 183 & 658 & 4533 & 324 & 22 \\
\hline COPPER & 84 & 83 & 79 & 45 & 66 & 70 & 107 & 86 & 58 & 102 & 43 & 44 & 82 & 56 & 1005 & 72 & 4,8 \\
\hline $\begin{array}{c}\text { COLOUR } \\
\text { GLASS }^{1)}\end{array}$ & 1016 & 572 & 583 & 282 & 465 & 509 & 649 & 464 & 380 & 486 & 182 & 175 & 674 & 296 & 6733 & 481 & 32 \\
\hline$B / W G L A S S^{1)}$ & 84 & 81 & 76 & 47 & 94 & 89 & 79 & 64 & 42 & 212 & 178 & 120 & 40 & 15 & 1221 & 87 & 5.8 \\
\hline$T R .+P S$ & 10 & 22 & 18 & 3 & 15 & 28 & 8 & 4 & 38 & 6 & 19 & 8 & 98 & 87 & 364 & 26 & 1.7 \\
\hline OTHER & 118 & 161 & 302 & 117 & 102 & 142 & 100 & 89 & 25 & 59 & 256 & 76 & 183 & 73 & 1803 & 129 & 8.5 \\
\hline TOTAL/DAY & 1726 & 1800 & 2161 & 959 & 1146 & 1482 & 1750 & 1252 & 1120 & 1726 & 1601 & 757 & 1856 & 1625 & 20,961 & 1497 & 100 \\
\hline
\end{tabular}

CRT: Monitors; PCB: Printed Circuit Board; PC: Personal Computers; HD: Hard Disk; FL: Flopp Disky; KB: Keyboard; B/W: Black and White; TR + PS: Transformer + Power Supply; Av/day: Average per day; Qty: Quantity. ${ }^{1)}$ The amount of glass from CRT and TV was counted after the separation of the panels from funnels. 
dom sampling. The results, not reported here, showed that interesting concentration and amount of precious metals were contained in the PCBs coming from the three sources reported in Table 1, PC, CRT and TV PCB. Extensive, systematic chemical analyses were then carried out on the single components of each type of PCBs, in order to pinpoint more accurately the precious metals content.

With this aim, analyses were carried out on the components of a representative sample of boards, namely 1) processors (Figure 1), integrated circuits (Figure 2), varistors, ceramic condensers, relays and MLCC capacitors (Figure 3) and other components belonging to Computer $\mathrm{PCBs}$; 2) integrated circuits and various parts belonging to Monitor PCBs, and 3) integrated circuits and various parts belonging to TV PCBs. In all three types of PCBs there were easy and difficult parts to remove, subjectively evaluated by the operators during disassembly. The results of the analyses are reported in Table 2.

The weigths of Computer-PCBs, Monitor-PCBs and

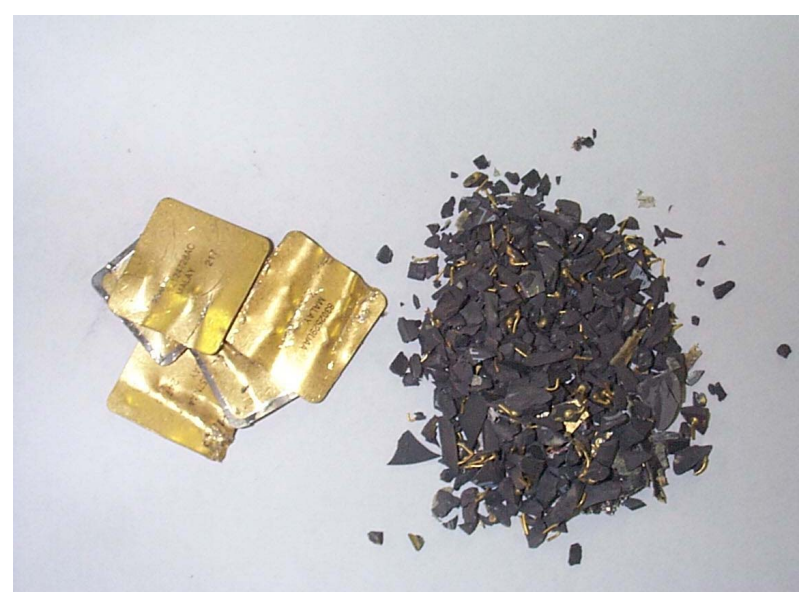

Figure 1. Computer Processors.

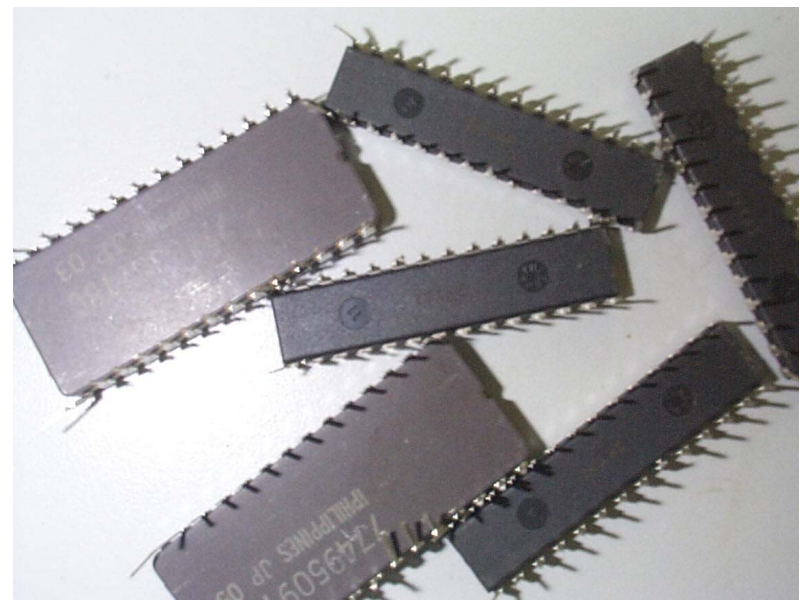

Figure 2. Integrated circuits (all applicances).
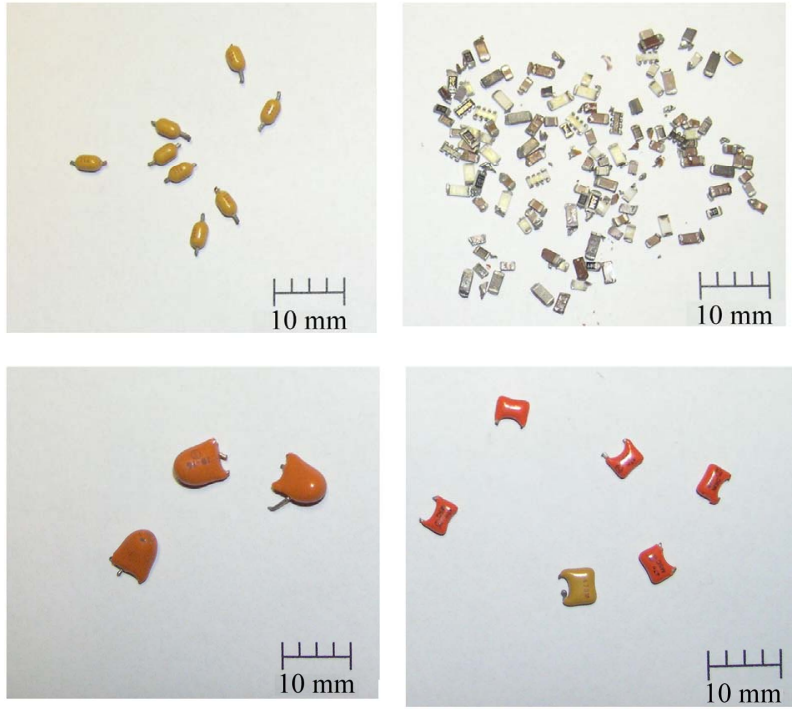

Figure 3. Varistors, ceramic condensers, relays and MLCC capacitors.

TV-PCBs contained in the representative sample, were about $23.0,28.0$ and $18.6 \mathrm{~kg}$ respectively and the processors and the integrated circuits were less than $10 \%$ in each board. The platinum content was negligible.

Although PCBs are the components of WEEE where precious metals are present, the highest concentrations of precious metals are in computer-PCBs with an average gold concentration of $344 \mu \mathrm{g} / \mathrm{g} \mathrm{Au}$ and $11.9 \mathrm{Pd} \mu \mathrm{g} / \mathrm{g}$, monitor and TV-PCBs showing lower concentrations.

As far as distribution of gold is concerned, computerPCBs contain the $96 \%$ of the entire gold contained in all three types of PCBs.

Most of gold was found in processors and integrated circuits in computer-PCB, with gold concentrations of 7004 and $701 \mu \mathrm{g} / \mathrm{g}$ respectively, while minor amounts were found in other components such as connectors. Most of the palladium was found in varistors, ceramic condensers, relays and, mainly, in MLCC capacitors showing a palladium concentration of $16808 \mu \mathrm{g} / \mathrm{g}$, that is the. $80 \%$ of the palladium contained in the entire board.

Table 2 also shows an economic balance to determine the value of the different components contained in the three types of boards, given by the content in gold and palladium. The values per gram of each valuable component in each board and the distribution of the value in the entire board are set out.

The most valuable boards are computer boards whose components are 95 and 43 times more profitable per gram than monitor and TV boards respectively.

It was noticed during disassembling of the preciousmetal bearing components that a few components, namely processors and integrated circuits, were more easily removable than others. 
Table 2. Grade and distribution of gold and palladium among the precious-metal bearing components of Computer, Monitor and TV printed circuit boards (PCB). The weight, the commercial value and their distribution among each kind of printed circuit boards are also reported.

\begin{tabular}{|c|c|c|c|c|c|c|c|c|c|c|c|c|}
\hline \multirow[t]{2}{*}{ Component } & \multirow[b]{2}{*}{ Weight } & \multirow[b]{2}{*}{ Distribution } & \multicolumn{4}{|c|}{$\mathrm{Au}$} & \multicolumn{3}{|c|}{$\mathrm{Pd}$} & \multirow[b]{2}{*}{ Value } & \multicolumn{2}{|c|}{$\mathrm{Au}+\mathrm{Pd}$} \\
\hline & & & Conc. & UM & Value & Value & Conc. & $\mathrm{UM}$ & Value & & Total Value & Value \\
\hline Computer PCB & $\mathrm{g}$ & $\%$ & $\mu \mathrm{g} / \mathrm{g}$ & $\mathrm{g}$ & USDc/g & $\%$ & $\mu \mathrm{g} / \mathrm{g}$ & $\mathrm{g}$ & USDc/g & $\%$ & USDc/g & $\%$ \\
\hline \multicolumn{13}{|l|}{ Easy-to-remove $^{1)}$} \\
\hline -Processors & 811 & 3.52 & 7004 & 5.68 & 24.7 & 72 & 2 & $1.6 \times 10^{-3}$ & 0 & 0 & 24.7 & 71 \\
\hline -Integrated Circuits & 2185 & 9.49 & 701 & 1.53 & 2.5 & 19 & 18 & $39.3 \times 10^{-3}$ & 0.19 & 2 & 2.69 & 19 \\
\hline $\begin{array}{l}\text { Hard-to-remove }{ }^{1)} \\
\text {-Varistors }+ \text { ceramic } \\
\text { condensors }\end{array}$ & 202 & 0.88 & $n$ & - & - & - & 2130 & 0.43 & 2.3 & 18 & 2.3 & 2 \\
\hline -Relais & 254 & 1.10 & $n$ & - & - & - & 160 & 0.04 & 0.2 & 2 & 0.2 & 0 \\
\hline -Capacitors MLCC & 111 & 0.48 & $n$ & - & - & - & 16,808 & 1.87 & 17.8 & 80 & 17.8 & 7 \\
\hline -All other components & 19,464 & 84.53 & 37 & 0.72 & 0.1 & 9 & $n$ & - & & - & 0 & 0 \\
\hline Total computer PCB & 23,028 & 100 & 344 & 7.93 & & 100 & 102 & 2.34 & & 100 & & 100 \\
\hline \multicolumn{13}{|l|}{ Monitor PCB } \\
\hline $\begin{array}{l}\text { Easy-to-remove } \\
\text {-Integrated Circuits }\end{array}$ & 40 & 0.14 & 154 & $6 \times 10^{-3}$ & 0.500 & 4 & 14 & $0.6 \times 10^{-3}$ & 0 & 1 & 0.500 & 100 \\
\hline $\begin{array}{l}\text { Hard-to-remove } \\
\text {-Various parts }\end{array}$ & 27,910 & 99.86 & 5 & $140 \times 10^{-3}$ & 0 & 96 & 4 & $112 \times 10^{-3}$ & 0 & 99 & 0.000 & 0 \\
\hline Total Monitor PCB & 27,950 & 100 & 5.21 & $146 \times 10^{-3}$ & & 100 & 4.0 & $113 \times 10^{-3}$ & & 100 & & 100 \\
\hline \multicolumn{13}{|l|}{ TV PCB } \\
\hline $\begin{array}{l}\text { Easy-to-remove } \\
\text {-Integrated Circuits }\end{array}$ & 415 & 2.22 & 315 & $130 \times 10^{-3}$ & 1.1 & 59 & 12 & $5.0 \times 10^{-3}$ & 0 & 5 & 1.100 & 58 \\
\hline $\begin{array}{l}\text { Hard-to-remove } \\
\text {-Various parts }\end{array}$ & 18,225 & 97.78 & 5 & $91.1 \times 10^{-3}$ & 0.018 & 41 & 5 & $91.1 \times 10^{-3}$ & 0 & 95 & 0.018 & 42 \\
\hline Total TV PCB & 18,640 & 100 & 11.9 & $222 \times 10^{-3}$ & & 100 & 5.2 & $96.1 \times 10^{-3}$ & & 100 & & 100 \\
\hline
\end{tabular}

$n:<1 \mathrm{mg} / \mathrm{kg} ;{ }^{1)}$ subjectively evaluated by the operators; UM: material units; conc: concentration; Quotation: Au 1000 USD/Oz; Pd 300 USD/Oz.

Table 3. Weights and grades of gold and palladium recoverable from the easy-to-remove components of the three types of printed circuit board found in the 14-day sample.

\begin{tabular}{|c|c|c|c|c|c|}
\hline \multirow{2}{*}{$\begin{array}{l}\text { Easy-to-remove components }{ }^{1)} \\
\text { Computer PCB }\end{array}$} & \multirow{2}{*}{$\begin{array}{c}\text { Weight }^{2)} \\
(\%)\end{array}$} & \multicolumn{2}{|c|}{$\mathrm{Au}$} & \multicolumn{2}{|c|}{$\mathrm{Pd}$} \\
\hline & & $(\mathrm{mg} / \mathrm{kg})$ & $\mathrm{mg} /$ day & $(\mathrm{mg} / \mathrm{kg})$ & $\mathrm{mg} / \mathrm{day}$ \\
\hline -Processors & 0.027 & 7004 & 2831 & 2 & 1 \\
\hline -Integrated Circuits & 0.073 & 701 & 766 & 18 & 20 \\
\hline \multicolumn{6}{|l|}{ Monitor PCB } \\
\hline -Integrated Circuits & 0.006 & 154 & 14 & 14 & 1 \\
\hline \multicolumn{6}{|l|}{ TV PCB } \\
\hline -Integrated Circuits & 0.008 & 315 & 38 & 12 & 1 \\
\hline Total ETR & 0.114 & 2137 & 3649 & 13,6 & 23 \\
\hline Total ETR kg & 23.9 & & & & \\
\hline Total ETR kg/day & 1.71 & & & & \\
\hline
\end{tabular}

${ }^{1}$ subjectively evaluated by the operators; ${ }^{2)}$ respect to $20961 \mathrm{~kg}$ (total WAEE collected in 14 days); 3) ETR: easy-to-remove components. 
Characteristics of easy-to-remove (ETR) gold and palladium-bearing components are reported in Table 3.

Most of gold is contained in these components which amount to $13 \%$ of the whole board and account for only $0.11 \%$ of all the RAEE entering the plant with a weight of $1.70 \mathrm{~kg} /$ day. The easily recoverable gold and palladium amount to 3.66 and $0.023 \mathrm{~g} /$ day, respectively.

Most of the palladium is contained in not-easy-to removed components (varistors, ceramic condensers and MLCC capacitors) that constitute about $0.012 \%$ of all theRAEE entering the plant and about $1.36 \%$ of the whole board.

\section{Discussion}

A method to selectively remove and sort out the valuable components from PCBs, in order to recover subsequently the precious metals, should minimize the environmental impact of the full treatment of the PCBs. At first, two solutions were considered: heating the board and the use of robots.

1) Heating of the board to weaken the soldering and enable the valuable components to be removed manually is not feasible because it is a very time-consuming process and requires environmental precautions for the worker in order to avoid the contact with the heavy metal vapours from the board.

2) Mechanical robots to perform such work automatically are not available everywhere, and are an expensive investment for small enterprises. At all events, processors and integrated circuits mainly consist of 2 parts, a lower one, the base, with pins that are soldered to the PCB and which it is very hard to remove, and an upper part, fixed on the base, which it is very easy to remove from the PCB just using a screwdriver and containing most of the gold.

As a consequence, the manual removal of the valuable parts of the board is a very simple operation that can be carried out in a short time, not calling for any particular skill, and by the same operators who manually dismantles each category of WEEE.

On the contrary, the components containing palladium, namely MLCC capacitors, varistors and ceramic condensers, are very small in size $(2-7 \mathrm{~mm})$ and are spread all over the board. The removal of such components is feasible just using a screwdriver, but it is time-consuming and its applicability clearly depends on the cost of labour; therefore the returns on the operation must be assessed and obviously depend on the cost of the labour at the place where dismantling takes place. It is not economic in Europe or the USA but will probably be very lucrative in emerging countries, where informal backyards recyclers today apply their work to the total amount of the PCB using simple techniques with an ex- tremely negative impact on the environment. Instead, and most importantly, the proposed process will permit the recovery of precious metal from an inorganic matrix not containing the precursors for the formation of organic micropollutants.

The obtained results demonstrate that the manual dismantling operation can be regarded as an easy and inexpensive method to sort out the valuable components of PCBs in WEEE and to reduce the volume of waste to be processed for the recovery the precious metals.

After this, further study was made of the extractive metallurgy of gold from this kind of sample. The matrix is the main difference between processing PCBs and primary raw materials to recover valuable elements. Silicon is the main component in the former, whereas silica is the main component in the latter. While this difference does not greatly affect hydrometallurgical processes, it plays an important role in pyrometallurgical operations, due to the difference in the oxidation state of the waste to be treated. Moreover, another difference between recovering gold from PCBs and from a primary raw material, is the volume of material involved in the process which is extremely small in processing PCBs for an equal amount of recovered metal.

The importance of the above data is due to the fact that for this process there is a substantial coincidence in industrial scale and laboratory scale, and therefore all the findings from the experiments in extractive metallurgy could be directly applied either to real industrial cases or to backyard recyclers in emerging countries.

\section{Conclusions}

A $20961 \mathrm{~kg}$ WEEE sample was collected in a Material Recycling Facility for 14 days to eliminate variations in feeding, and the components of Printed Circuit Boards , coming from computers, monitors and TV-sets, were analyzed for their Au and Pd contents. Most of the gold and palladium is contained in computer PCBs. The gold is present at an average concentration of $344 \mu \mathrm{g} / \mathrm{g}$ in the entire board but is also found in processors (72\%) and integrated circuits $(19 \%)$ of the board at concentrations of $7004 \mu \mathrm{g} / \mathrm{g}$ and $701 \mu \mathrm{g} / \mathrm{g}$, respectively and $2400 \mu \mathrm{g} / \mathrm{g}$ as a total. The amount of these two gold-bearing components of computer-PCBs is about $0.11 \%$ of the whole sample collected and $13 \%$ with respect to the whole board. Both components have been considered "easy" to remove by the operators, hence the gold is easily recoverable. As far as palladium is concerned, the metal is present in MLCC capacitors (80\%) and in varistors and ceramic condensers (18\%) at a concentration of 16808 $\mu \mathrm{g} / \mathrm{g}$ and $2130 \mu \mathrm{g} / \mathrm{g}$ respectively with an average concentration of $102 \mu \mathrm{g} / \mathrm{g}$ in the whole board. The palladium-bearing components represent the $0.012 \%$ of the 
entire sample collected and $1.36 \%$ of the whole board. Unfortunately, the palladium-bearing components of computer-PCBs are hard to remove from the board and the metal is not easily recoverable.

Extraction of precious metals from monitors and TV boards does not seem worth studying due to the low values recoverable.

\section{Acknowledgements}

This paper is in memory of our collegue Massimo Delfini who greatly helped us in carrying out the research. The authors want to thank the Association for Georesource Engineering of Rome, Italy (CINIGEO) for the precious contribution supplied to the present work.

\section{REFERENCES}

[1] J.-C. Lee, K. Jin-Ki, Y. Jung-Il and C. Hun-Sang, "Technology for Recovering Valuable Metals from Printed Circuit Boards (PCBs) of the Used Personal Computer," Chawon Risaikring, Vol. 7, No. 3, 1998, pp. 58-66.

[2] C.-H. Lee, C.-T. Chang, K.-S. Fan, C. Tien and C. Lee, "An Overview of Recycling and Treatment of Scrap Computers," Journal of Hazardous Materials, Vol. 114, No. 1-3, 2004, pp. 93-100.

[3] B. Manty, N. Colon and L. Battista, "State-of-the-Art Demanufacturing of Electronic Equipment for Reuse and Recycling (Deer2)," Proceedings of the Air \& Waste Management Association's Annual Conference \& Exhibition, 93rd, Salt Lake City, 18-22 June 2000, pp. 60956104

[4] H. Kang and Y. J. Schoenung, "Electronic Waste Recycling: A Review of U.S. Infrastructure and Technology Options," Resources, Conservation and Recycling, Vol. 452005 , pp. 368-400.

doi:10.1016/i.resconrec.2005.06.001

[5] W. Z. He, G. M. Li; X. F. Ma, H. Wang, J. W. Huang, M. $\mathrm{Xu}$ and C. J. Huang, "WEEE Recovery Strategies and the WEEE Treatment Status in China," Journal of Hazardous Materials, Vol. 136, No. 3, 2006, pp. 502-512. doi:10.1016/j.jhazmat.2006.04.060

[6] K. Feszty, C. Murchison, J. Baird and G. Jamnejad, “Assessment of the Quantities of Waste Electrical and Electronic Equipment (WEEE) in Scotland," Waste Management \& Research: The Journal of the International Solid Wastes and Public Cleansing Association, ISWA, Vol. 21, No. 3, 2003, pp. 207-217.

[7] A. Karagiannidis, A. Papadopoulos, N. Moussiopoulos, G. Perkoulidis, T. Tsatsarelis and A. Michalopoulos, "Characteristics of Wastes from Electric and Electronic Equipment in Greece: Results of a Field Survey," Proceedings of the International Conference on Environmental Science and Technology, 8th, Myrina, 8-10 September 2003, pp. B353-B360

[8] L. Schebek, "Disposal of Electronic Scrap in BadenWuerttemberg: A Life-Cycle View on Future Recycling Options-Outline of a Study," Wissenschaftliche Berichte-
Forschungszentrum Karlsruhe, 2004, pp. F1/1-F1/5.

[9] R. Hischier, P. Wager and J. Gauglhofer, "Does WEEE Recycling Make Sense from an Environmental Prospective? The Environmental Impacts of the Swiss Take-Back and Recycling Systems for Waste Electrical and Electronic Equipment (WEEE)," Environmental Impact Assessment Review, Vol. 25, 2005, pp. 525-539. doi:10.1016/j.eiar.2005.04.003

[10] S. Zhang and E. Forssberg, "Intelligent Liberation and Classification of Electronic Scrap," Powder Technology, Vol. 105, 1999, pp. 295-301. doi:10.1016/S0032-5910(99)00151-5

[11] A. Seemann, H. Schreiber, S. Krishna and T. Radha, "Waste Recycling in India," Muell und Abfall, Vol. 40, No. 6, 2008, pp. 306-310.

[12] T. Hainault and D. S. Smith, "Minnesota's Multistakeolder Approach to Managing Electronic Products at End-of-Life," Proceeding of IEEE International Symposium on Electronics and Environment, 2000, pp. 310-317

[13] J. K. Y. Chan, Y. Xu, Y. Liang, L.X. Chen, S. C. Wu, C. K. C. Wong, C. K. M. Leung and M. H. Wong, "Dioxin Levels in Human Specimens from Taizhou, an ElectronicWaste Recycling Site in Eastern China," Organohalogen Compounds, Vol. 69, No. 291, 2007, pp. 1-3.

[14] G. H. Xing, K. Y. C. Janet, O. W. L. Anna, C. W. Sheng and M. H. Wong, "Environmental Impact and Human Exposure to PCBs in Guiyu, an Electronic Waste Recycling Site in China," Environment International (2008), Vol. 35, No. 1, 2009, pp. 76-82.

[15] L. Chen, J. X. Guo, Z. Z. Yu, J. Ying, B. S. Ji, J. Qi, P. L. Li, J. Jing, C. W. Tang and M. C. Xue, "Levels of Lead, Cadmium, Copper in Blood and urine And Frequencies of Micronucleated Binucleated Cells among Residents in an Electronic Waste Recycling Site in China," Huanjing Yu Zhiye Yixue, Vol. 25, No. 5, 2008, pp. 442-445.

[16] Y. Li, H. Xia, K. Z. Liang, Z. Bao, J. C. Gang, W. G. Cheng, X. L. Jun, J. C. Song and J. X. Xi, "Umbilical Cord Blood Chromium Level of Newborns in Electronic Waste Recycling Area," Aibian, Jibian, Tubian, Vol. 19, No. 5, 2007, pp. 409-411.

[17] S. X. Liang, Z. Qian, F. Q. Zhan, R. Z. Xing, Z. Y. Zhong and B. X. Xiao, "Levels and Distribution of Polybrominated Diphenyl Ethers in Various Tissues of Foraging Hens from an Electronic Waste Recycling Area in South China," Environmental Toxicology and Chemistry, Vol. 27, No. 6, 2008, pp. 1279-1283. doi:10.1897/07-518.1

[18] W. J. Deng, P. K. K. Louie, W. K. Liu, X. H. Bi, J. M. Fu and M. H. Wong, "Atmospheric Levels and Cytotoxicity of PAHs and Heavy Metals in TSP and PM2.5 at an Electronic Waste Recycling Site in Southeast China," Atmospheric Environment, Vol. 40, No. 36, 2006, pp. 69456955. doi:10.1016/j.atmosenv.2006.06.032

[19] N. Menad and B. Bjorkman, "EPD Congress, Nashville, Tennessee," The Mineral Metals \& Materials Society, 2000, pp. 231-243.

[20] S. Kitamoto, K. Yonezu, H. Ohashi, Y. Motomura, Y. Kobayashi, Y. Okaue, A. Miyazaki, K. Watanabe and T. 
Yokoyama, "Coprecipitation of $\mathrm{Au}(\mathrm{III})$ Complex Ions with Iron(III) Hydroxide and Their Spontaneous Reduction," Journal of MMIJ, Vol. 123, No. 8, 2007, pp. 406412. doi:10.2473/journalofmmij.123.406

[21] S. G. Zhang, J. T. Jian and H. Q. Xuan, "Method for Recovering Metals from Electronic Waste by Electrolysis," Faming Zhuanli Shenqing Gongkai Shuomingshu, 2008, $7 \mathrm{pp}$.

[22] A. Buekens, "Studies on Dioxin Formation in Metallurgical Processes," Chloride Metallurgy 2002: Practice and Theory of Chloride/Metal Interaction, Annual Hydrometallurgy Meeting, 32nd, Montreal, 19-23 October 2002, pp. $87-112$
[23] H. Matzing, "A Simple Kinetic Model of PCDD/F Formation by De Novo Synthesis," Chemosphere, Vol. 44, No. 6, 2001, pp. 1497-1503. doi:10.1016/S0045-6535(00)00374-X

[24] M. Ferrini, A. Manni and P. Massacci, "Chemical Analysis by ICP-AES of Jewellery Waste in Italy," Proceedings of Second Biennial International Conference on Chemical Measurement and Monitoring of the Environment. EnviroAnalysis'98, 1998, pp. 501-506.

[25] A. V. Zelyanskii, L. V. Zhukova and G. A. Kitaev, "Solubility of $\mathrm{AgCl}$ and $\mathrm{AgBr}$ in $\mathrm{HCl}$ and $\mathrm{Hbr}$," Inorganic Materials, Vol. 37, No. 5., 2001, pp. 523-526. 